ISSN: 2337-5957 / E-ISSN: 2655-2833

\section{PUSAKA \\ Jurnal Khazanah Keagamaan \\ Vol. 7, No. 2, November 2019}




\section{PUSAKA}

\section{Jurnal Khazanah Keagamaan}

Vol. 7, No. 2, November 2019

PEMBINA

REDAKTUR AHLI

MITRA BESTARI

PEMIMPIN REDAKSI

DEWAN REDAKSI

KESEKRETARIATAN

Lay Out

ALAMAT REDAKSI
: H. Saprillah, M.Si.

: Dr. H. Abd. Kadir M., M.Ag. (Agama, Balitbang Agama Makassar)

: Dr. Ulfiani Rahman (Kajian Dirasat Islamiyah, Universitas Negeri Alauddin Makassar)

Dr. Mustolehudin (Kajian Pendidikan Keagamaan, Balai Litbang Agama Semarang)

Dr. H. Muhaemin (Kajian Pendidikan Agama, Insitut Agama Islam Negeri Palopo)

Dr. Muhammad Adlin Sila, Ph.D. (Kajian Agama dan Masyarakat)

Dr. H. Idham, M.Pd. (Kajian Agama dan Tradisi Keagamaan)

: Muh. Subair, S.S., M.P.I.

: Abu Muslim, S.HI., M.HI. Syarifuddin, S.S., M.Hum.

H. Muhammad Sadli Mustafa, S.Th.I., M.Pd,I

Wardiah Hamid, S.Ag, M.Hum

Drs. Ilham, M.Si.

: Amru Ichwan Alwy, S.IPI.

Darwis, S.Pd.I.

Risma Yuliana Wahab, S.Kom

Nasri, S.Sos.

Bohari

: Nur Arisal

: Balai Penelitian dan Pengembangan Agama Makassar

Jl. A.P. Pettarani No. 72 Makassar 90222

Telp. 0411452952 Fax. 0411452982

Email: pusakajurnal@gmail.com 


\section{PUSAKA \\ Jurnal Khazanah Keagamaan \\ Vol. 7, No. 2, November 2019}

\section{DAFTAR ISI}

Islam Kultural di Sulawesi Selatan: Keselarasan Islam Dan Budaya Abd. Kadir Ahmad

Pesantren dan Kebangsaan

Bisri Effendy

Prakarsa Bugis-Mandar dalam Pendidikan Keagamaan di Lalowura Loea Kolaka Timur Sulawesi Tenggara

Muh. Yahya dan Muh. Subair

Peran Orang Bugis Mengembangkan Pendidikan Islam di Kota Injil Manokwari

Akmal dan Abu Muslim

KH. Ahmad Maruf Biografi dan Perannya Mengembangkan Islam di Baruga Kabupaten Majene

Syarifuddin

Nilai-Nilai Luhur dalam Pappasang Masyarakat Mandar

Husnul Fahima Ilyas

Relevansi Sejarah dan Budaya Bagi Pembangunan Sulawesi Barat Idham

Pola Interaksi Migran Bugis dalam Pengembangan Pendidikan Agama di Kota Bitung 


\section{PENGANTAR REDAKSI}

PUSAKA Jurnal Khazanah Keagamaan Vol. 7, No. 2, November 2019 sudah menapak akreditasi SINTA 5. Ada banyak catatan untuk perbaikan kualitas jurnal ini dalam aspek teknis dan substansi artikel yang telah diterbitkan. Pengetatan chek plagiasi juga menjadi perhatian yang harus dijalankan dengan konsisten terhadap semua tulisan yang masuk. Artikel yang masuk dengan unsur plagiasi di atas $20 \%$ tanpa kompromi harus ditolak dan tidak lagi boleh dimuat.

Pusaka Jurnal Khazanah Keagamaan edisi ini mengetengahkan beberapa artikel dari penulis ternama. Artikel pertama ditulis oleh Abd. Kadir Ahmad yang membahas tentang pertemuan budaya lokal dengan agama Islam di Sulawesi Selatan. Dia mengungkap adanya peran ulama dalam menyeimbangkan proses dialog budaya dan agama dengan menyerap nilai-nilai dari keduanya. Sehingga masyarakat Sulawesi Selatan dapat menikmati perayaan budaya warisan leluhurnya sambil tetap menjalankan ajaran agama dengan perasaan bahagia. Artikel ini bersesuaian dengan nilai luhur dalam pappasang yang ditulis oleh Husnul Fahimah Ilyas, dan peran ulama KH. Ahmad Maruf dalam pengembangan ajaran Islam yang ditulis oleh Syarifuddin. Artikel kedua ditulis oleh Bisri Effendy yang mengulas tentang pesantren dan kebangsaan. Tulisan ini membincang tentang peran Nahdatul Ulama dan Muhammadiyah dalam pentas sejarah yang diabaikan. Artikel ketiga adalah tulisan tentang migran Bugis-Mandar di Desa Lalowura Kolaka Timur yang ditulis oleh Muh. Yahya dan Muh. Subair. Artikel keempat juga terkait peren migran Bugis dalam pendidikan keagamaan di Manokwari oleh Abu Muslim. Demikian pula artikel kedelapan yang juga terkait dengan migran Bugis di Sulawesi Utara yang ditulis oleh Muhammad Nur.

Akhirnya, kami ucapkan terima kasih tak terhingga kepada Kepala Balai Litbang Agama Makassar, yang senantiasa memberi dukungan dalam proses penerbitan Jurnal ini. Sehingga dapat terbit dalam versi cetak maupun dalam versi online. Terima kasih kepada semua penulis dan salam hangat kepada semua pembaca.... 


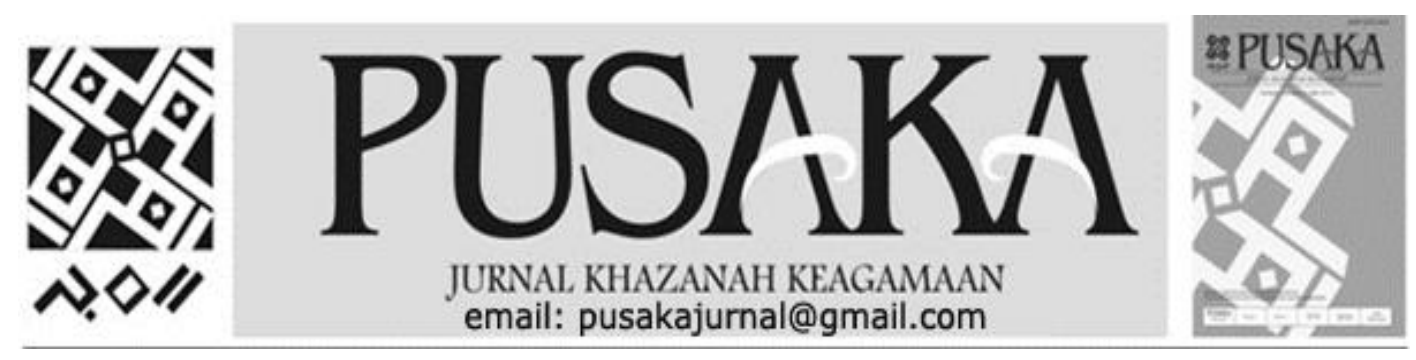

\title{
Peran Orang Bugis Mengembangkan Pendidikan Islam di Kota Injil Manokwari
}

\section{The Bugis Role to Developing Islamic Studies in Manokwari The City of Gospel}

\author{
Akmal \\ Institut Agama Islam Negeri Kendari \\ Jl. Sultan Qaimuddin No. 17 Kota Kendari \\ Email: puangakmal77@gmail.com
}

\author{
Abu Muslim \\ Balai Penelitian dan Pengembangan Agama Makassar \\ J1.A.P.Pettarani No.72 Makassar. Telp:0411-452952 \\ Email: abumuslim@kemenag.go.id
}

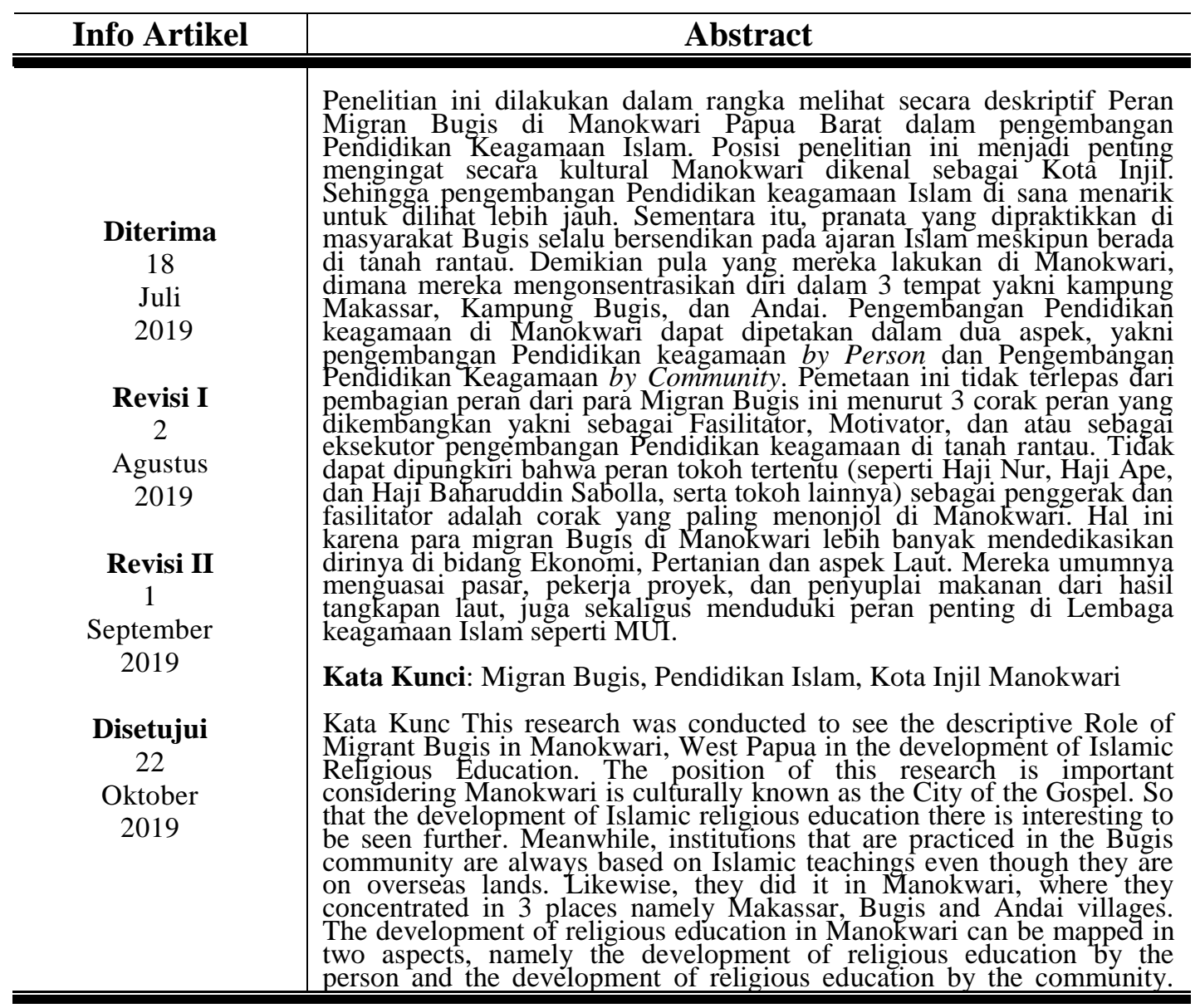




\begin{tabular}{l|l}
\hline This mapping is inseparable from the division of roles of the Bugis \\
Migrants according to the 3 roles that were developed namely as a \\
Facilitator, Motivator, and / or executor of the development of religious \\
education in the overseas land. It cannot be denied that the role of certain \\
figures (such as Haji Nur, Haji Ape and Haji Baharuddin Sabolla, as \\
well as other figures) as the mobilizer and facilitator are the most \\
prominent features in Manokwari. This is because the Bugis migrants in \\
Manokwari dedicate themselves more in the fields of Economy, \\
Agriculture, and Sea aspects. They generally have an important role in \\
the market, project workers, and suppliers of food from sea catches, as \\
well as occupying an important role in Islamic religious institutions such \\
as the MUI. \\
Keywords: Bugis Migrants, Islamic Education, Gospel City of \\
Manokwari
\end{tabular}

\section{PENDAHULUAN}

Orang-orang Bugis yang dalam ingatan romantisisme sejarah masa lalu selalu diceritakan oleh orang-orang tua Bugis dahulu (meskipun cenderung subjektif dan terlalu positivistik) bahwa orang Bugis itu, jika sudah merantau bisa menjadi sangat heroik, hebat, dan mendominasi, terutama di bidang ekonomi, konsolidasi, dan pertanian, (dengan filosofi sompe' yang dikenal dengan istilah Tellu Cappa' (Cappa lila, Cappa Kawali, dan Cappa Katawang). Bahkan disebutkan bahwa prospek kewirausahaan orang Bugis dapat menjadi kekuatan progresif perekonomian Indonesia (Ammarell 2002). Beberapa catatan para penulis sebelumnya tentang informasi kekuatan ekonomi orang Bugis dapat dilihat dalam (Abidin 1983), (Mattulada 1985), (Andaya 1995), (Pelras dalam Rahman 2006), (Hamid 2005), (Kesuma 2004), (Lineton 1975).

Migrasi bagi masyarakat Bugis merupakan praktik yang sudah menjadi bagian dari tradisi mereka. Secara filosofis mereka memandang bahwa perlu adanya migrasi untuk menegakkan kehidupan. Kalimat 'kegisi monro sore' lopie', kositu tomallabu se'ngereng" (dimana perahu terdampar, di sanalah kehidupan ditegakkan). Dengan kalimat seperti ini, maka ada pengalaman panjang yang terjadi secara turun temurun.
Dipercayai oleh masyarakat Bugis sehingga menjadikan migrasi sebagai sebuah kesempatan untuk memperoleh kehidupan lebih baik. Dengan demikian, aktivitas migrasi merupakan bagian yang tidak asing, sekaligus menjadi pilihan utama dengan pelbagai alasan yang melatarbelakanginya. Bahkan dengan migrasi ini melembaga dalam kebudayaan yang dijalankan dari waktu ke waktu (Wekke 2017).

Ada seribu satu macam cara bagi orang Bugis untuk bisa melakukan adaptasi pada setiap daerah yang menjadi sasaran rantau, meski beberapa pada umumnya erat kaitannya dengan ekonomi, dan pertanian, serta kelautan, namun juga tidak menyurutkan pola adaptif pada aspek lainnya. Tidak jarang, posisi orang Bugis kadang pula diasosiasikan peyoratif, karena cukup punya Power dalam konteks penguasaan wilayah dengan mengandalkan kekuatan fisik, sehingga disegani dalam aspek-aspek tertentu (Muslim 2019).

Ruang sosial yang diperankan masyarakat Bugis rantau terdapat beragam varian "pengakuan" yang melekat, dan atau dilekatkan pada komunitas yang gemar merantau ini (Ammarell 2016: 209). Kondisi yang ditemui di beberapa daerah, dimana mereka (baca: migran Bugis) itu hidup berkelompok, menunjukkan ragam diaspora. 


\begin{abstract}
Mereka yang 'benar-benar' Bugis atau dalam artikulasi kedaerahannya dikenal dengan Bugis toto' (ada juga yang menyebutnya Bugis antero), pada dasarnya memiliki corak bermigrasi yang sama, semisal berbahasa Bugis dalam kehidupan sehari-harinya, bergaul 'hanya' dengan sesamanya orang Bugis, memiliki kecenderungan berdagang dan bertani, serta selalu 'berusaha" terlihat 'berani' di hadapan masyarakat suku lain yang dijumpainya, dan yang terpenting adalah memahami secara mendalam arti penting siri, lempu, getteng, wari, dan ada tongeng.
\end{abstract}

Keberanian dan ciri khas itu pada dasarnya dipengaruhi oleh (setidaknya) tiga falsafah rantau yang senantiasa dipesankan oleh orangorang tua 'mereka' sebelum membulatkan tekad bermigrasi, dan atau merantau ke luar kampung. Falsafah itu dikenal dengan "Tellu Cappa” (Tiga Ujung), yakni Cappa Lila (Ujung Lidah) yang mencerminkan kebulatan tekad dan keahlian berargumentasi khususnya dalam hal ekonomi, kedua Cappa Kawali (Ujung Badik) berupa keberanian terhadap segala hal, tanpa mengenal rasa takut yang di dalamnya juga terakumulasi dalam siri (rasa malu), dan yang ketiga adalah Cappa Laso' (Ujung Kemaluan), dimana perantau Bugis memiliki kebiasaan kawin mawin dengan penduduk setempat, sebagai bagian yang tidak terpisahkan dari cara mereka menipiskan jarak secara sosial, serta memperkuat pengaruh secara kekeluargaan, terlebih jika yang dipersunting adalah turunan raja dan atau bangsawan setempat. Ketiga falsafah itu, biasanya melekat sangat dalam pada mereka yang benar-benar memiliki darah keturunan Bugis toto.

Dalam catatan perantauan orang Bugis dikemukakan bahwa persebaran orang Bugis dari tanah kelahiran ke seluruh pelosok nusantara antara lain disebabkan oleh peristiwa politik dan gejolak sosial masa lalu di Sulawesi Selatan. Menurut Anhar Gonggong (Gau 2010), gelombang perantauan orang Bugis ke Papua dapat dibagi ke dalam dua tahap utama, yaitu: Tahap Pertama: Tahun 1962-1968 Sebelum Penentuan Pendapat Rakyat (PEPERA) berlangsung pada tahun 1969, sudah terdapat kelompok-kelompok kecil orang Bugis yang merantau ke Papua. Sebagian dari mereka adalah golongan yang hendak melepaskan diri dari ketakutan dan trauma setelah peristiwa pemberontakan Darul Islam/Tentara Islam Indonesia (DI/TII). Satu isu menarik bahwa perantau-perantau Bugis pada tahap ini adalah golongan yang berkemampuan dan memiliki kekayaan dan harta benda di kampung asal mereka. Selain itu, motif dan tujuan mereka bermigrasi ke Papua adalah mencari peluang untuk meluaskan jaringan perniagaan mereka.

Tahap Kedua: Tahun 1970-an Kedatangan orang Bugis ke Papua pada waktu itu didasarkan pada motif ekonomi. Namun, faktor situasi Sulawesi Selatan di era tahun 1970-an dengan kekuatan dan kekuasaan Orde Baru yang sangat dominan, juga menjadi pendorong terhadap orang Bugis untuk meninggalkan Tanah Bugis. Dengan kenyataan seperti itu, migrasi pada saat itu, bukan saja bertujuan untuk memperluas perdagangan, melainkan juga untuk mencari wilayah yang lebih aman untuk didiami. 
Pada era inilah, telah terjadi migrasi orang Bugis secara besarbesaran dari Sulawesi Selatan ke kawasan lain di Nusantara (diperkirakan 200,000 orang). Di antara kawasan Nusantara yang paling banyak dituju oleh para perantau Bugis ialah Kalimantan (timur dan utara) dan Papua.

Dari Manokwari, Sorong, Jayapura, Wamena, Nabire, Timika, hingga Merauke, pendatang terus berdatangan. Ini terjadi sejak migrasi besar-besaran mengalir melalui program transmigrasi. Di semua wilayah, dari kabupaten hingga kecamatan, bahkan kampung, pendatang menguasai pasar bahan kebutuhan pokok hingga jaringan transportasi dan jasa. Potret Papua dan Papua Barat telah berubah. Ke mana arah pembangunan sumber daya alam dan sumber daya manusia di "bumi cenderawasih" itu akan dibawa masih belum jelas. Program Percepatan Pembangunan Papua dan Papua Barat (P4B) tidak fokus dan tidak memiliki desain utama. Pembangunan masih mengedepankan infrastruktur sehingga belum menyentuh hak-hak dasar masyarakat asli. Ketua Majelis Masyarakat Papua Provinsi Papua Barat Vitalis Yumte, awal Juli lalu di Manokwari, mengatakan, pembukaan akses ekonomi melalui pembangunan infrastruktur semakin membuat pendatang berbondong-bondong datang. Akibatnya, masyarakat asli Papua semakin tersingkir. Pembangunan di bidang ekonomi, terutama pasar, tidak diikuti dengan pemberdayaan perekonomian masyarakat asli. Akibatnya, masyarakat asli kalah bersaing dalam berdagang.

Sementara itu, dalam konteks migrasi orang Bugis di tanah Papua, tentu selain dari aspek sejarah kedatangan mereka (para Pasompe Ogi itu) sebagaimana yang ditulis oleh Anhar Gonggong, sebagai bagian integral dalam keputusan mereka mencari jati diri, dan mengakrabkan diri dengan warga tempatan. Juga harus dilihat secara kontekstual posisi Orang Bugis dan para migran lainnya sebagai pendatang di tanah Papua yang dalam beberapa kajian menjadi salah satu problem tersendiri di tanah Papua. Betapa tidak, kedatangan para migran itu membuat orang asli Papua sedikit "tersudut", khususnya dalam hal pengembangan dan tata kelola perekonomian. Studi yang dilakukan LIPI (Elisabeth et al. 2004) menggambarkan fragmentasi yang terjadi di kalangan internal orang Papua asli dalam berbagai persoalan. Ada empat hal yang menjadi poin LIPI dalam mengidentifikasi problem sosial di tanah Papua antara lain: (1) Marginalisasi orang asli Papua di bidang ekonomi terutama dalam hal makin bertambahnya gelombang migrasi penduduk. (2) Program pembangunan di tanah Papua yang belum berjalan maksimal dalam mengatasi kesenjangan ekonomi. (3) Efek Jakarta terhadap Papua yang dinilai ada hal mendasar dalam aspek sejarah yang cukup rumit, (4) Adanya anggapan ketidakadilan negara terhadap masyarakat Papua (Suryawan 2014).

Empat poin itu pada dasarnya juga menjadi aspek penting untuk diperhatikan, dimana posisi sebagai pendatang menjadi cukup resistan khususnya bagi orang Bugis, yang kedalaman pengaruh dan perannya di bidang ekonomi menjadi suatu hal yang sangat menonjol, tidak terkecuali di tanah Papua. 
Betapa tidak, orang Bugis di Manokwari khususnya sangat dominan dalam hal penguasaan pasar, dan juga beberapa ruang ekonomi lainnya antara lain bisnis properti dan infrastruktur juga menjadi hajat hidup penting dalam keberlangsungan orang Bugis di Manokwari Papua Barat. Jika cara membaur dan pola komunikasi tidak dibangun secara baik, mulai dari tatanan masyarakat akar rumput sampai kepala Suku dan atau tokoh adat, maka bukan tidak mungkin keberadaan para migran bisa menjadi salah satu yang terus menerus dirongrong. Oleh karena itu, pendekatan kultural dan komunikasi intensif baik melalui pergaulan personal, maupun kelembagaan dalam hal ini KKSS (Kerukunan Keluarga Sulawesi Selatan) yang menaungi pilar-pilar organisasi kedaerahan asal Sulsel di tanah Papua, adalah aspek penting yang senantiasa harus dibangun dengan baik.

Masyarakat Bugis dalam mendiami Papua memulai dari aktivitas ekonomi. Tetapi tidak berhenti di situ saja. Kemudian mereka mulai mengembangkan aspek pendidikan. Beberapa alumni dari Pesantren Darul Dakwah wal Irsyad (DDI) di Sulawesi Selatan mendirikan madrasah. Dimulai di Timika, dan kemudian bertambah di Jayapura dan Sorong. Gerakan ini dilakukan untuk memenuhi kebutuhan masyarakat Bugis akan pendidikan agama. Sementara pendidikan agama yang terselenggara di Papua lebih pada tipikal kebudayaan Jawa dan Sunda. Dengan pengembangan madrasah DDI akan menjadi sarana dalam meneguhkan kesadaran nilai-nilai utama Bugis (Wekke 2017). Kajian tentang migran Bugis di berbagai daerah di Indonesia dari berbagai aspek telah dilakukan oleh banyak penulis.
Akan tetapi, kajian dari aspek keagamaan, khususnya peran mereka dalam pengembangan pendidikan keagamaan masih sangat terbatas. Kajian tentang hal ini dipandang penting untuk memperoleh informasi untuk keperluan pengembangan dalam rangka mengatasi masalah dan mengembangkannya ke arah yang lebih baik pada masa datang.

Berdasarkan itulah sehingga penelitian ini didesain sedemikian rupa dalam beberapa problem riset yakni: (1) Bagaimanakah gambaran tentang kehidupan migran Bugis di Manokwari secara umum? (2) Bagaimanakah peran migran Bugis dalam bidang sosial keagamaan, khususnya pengembangan pendidikan keagamaan di daerah ini? (3) Seperti apakah dukungan yang diperlukan untuk mengoptimalkan pengembangan pendidikan keagamaan di Manokwari?.

Sesuai dengan permasalahan di atas, maka penelitian ini bertujuan untuk:

1. Memberikan gambaran tentang kehidupan migran Bugis di Manokwari secara umum;

2. Menjelaskan peran migran Bugis di daerah ini dalam bidang sosial, khususnya pengembangan pendidikan keagamaan;

3. Mengidentifikasi masalah yang dihadapi dan menemukan langkah-langkah nyata yang operasional untuk pengembangan pendidikan keagamaan di daerah ini.

Adapun kegunaan penelitian ini yakni, menyediakan informasi tentang peran individual dan kolektif orang Bugis dan warga masyarakat lainnya di Manokwari Papua Barat dalam 
pengembangan kehidupan keagamaan yang difokuskan pada pendidikan keagamaan Islam. Peran ini dipandang penting karena dilakukan atau dipelopori oleh kaum migran yang mempunyai nilai-nilai budaya yang khas dan pengalaman keagamaan di daerah asalnya. Peran itu lebih penting lagi, bila dilakukan secara bersinergi dengan penduduk asli atau komunitas lainnya. Pola-pola komunikasi, adaptasi dan kerja sama antar golongan dalam masyarakat dari sebuah bangsa yang besar dengan jumlah etnis yang banyak perlu diketahui untuk pengembangan ke depan. Pengetahuan tentang peran etnis ini memungkinkan untuk dikembangkan lebih luas karena keberadaan migran Bugis menempati wilayah yang tersebar di seluruh Indonesia. Pemeliharaan dan penguatan identitas kultural dari etnik yang religius perlu ditingkatkan untuk penguatan bangsa yang religius.

\section{Ruang Lingkup dan Batasan Operasional}

Penelitian ini dilaksanakan di Provinsi Papua Barat, yakni Kota Manokwari. Di kabupaten ini dipilih satu wilayah konsentrasi orang Bugis berkumpul, yakni Kampung Makassar Kelurahan Wosi Distrik Manokwari Barat Kota Manokwari sebagai sasaran penelitian. Pertimbangan di dalam memilih lokasi antara lain: 1) Di kelurahan ini terdapat komunitas Bugis yang jumlahnya cukup besar; 2) Di tempat ini aktivitas pendidikan keagamaan Islam sudah berkembang dan perlu dilanjutkan serta memerlukan penguatan dan dukungan dari pihak lain, termasuk pemerintah.

Penelitian ini dibatasi pada peran migran Bugis dalam menyelenggarakan pendidikan keagamaan Islam yang bersifat nonformal dan informal. Dalam kaitan ini pengamatan dan wawancara difokuskan pada peran mereka dalam mengelola rumah ibadah yang juga difungsikan sebagai sarana penyelenggaraan pendidikan keagamaan dalam bentuk mangaji tudang (kajian kitab sambil duduk), pendidikan Al-Quran, dsb. Pendidikan formal di madrasah dan perguruan tinggi Islam diuraikan juga dalam kaitannya dengan peran lembaga tersebut atau orang yang berkecimpung di dalamnya dalam pengembangan pendidikan keagamaan.

\section{Kerangka Teori dan Kajian Pustaka}

Penelitian ini berpijak pada teori yang dikemukakan dalam kajian antropologi, yaitu peran nilai-nilai budaya bagi komunitas yang memilikinya dan kaitannya dengan agama. Geertz menyatakan bahwa agama bukan hanya bagian dari kebudayaan, tetapi juga adalah inti dari kebudayaan. Sebagai inti kebudayaan (cultural core) agama menjadi pedoman hidup, penentu arah dan ketepatan kehidupan yang dipandang baik atau buruk (Saifuddin, 2011: 74). Kebudayaan dalam kajian antropologi menunjuk pada keseluruhan pengetahuan manusia sebagai makhluk sosial yang digunakan untuk memahami lingkungannya serta pengalamannya dan yang menjadi pedoman tingkah lakunya (Pusat Pembinaan dan Pengembangan Bahasa Kementerian Pendidikan Nasional, 2009: 149). Dalam kaitan ini, suku bangsa Bugis memiliki nilai-nilai. Nilai-nilai utama bagi orang Bugis, menurut Rahman Rahim mencakup: 1) kejujuran (lempu); 2) kecendekiaan (acca); 3) kepatutan (assitinajang); 4) keteguhan (getteng); 5) usaha (penulis: 
reso) (Rahim, 1985: 145-165). Sejumlah nilai utama itu sesungguhnya sejalan dengan agama Islam, namun demikian Islam sebagai sumber nilai bagi orang Bugis perlu disebutkan tersendiri. Perpaduan nilai-nilai utama yang diwarnai atau dipengaruhi ajaran Islam telah menjadi pedoman hidup dan dipergunakan orang Bugis dalam berinteraksi dengan lingkungannya. Orang-orang Bugis mengidentifikasi diri sebagai individu muslim sesuai kapasitas pemahaman dan penghayatannya dalam menjalankan aktivitas hidup sehari-hari dan mewujudkan keinginan dan harapannya.

Semangat keagamaan migran Bugis terlihat dalam partisipasi mereka dalam kegiatan keagamaan dan mengelola pranata rumah ibadah dan lembaga pendidikan keagamaan atau madrasah. Dilaporkan bahwa di Sulawesi Tengah, organisasi Darul Dakwah Wal Irsyad yang berpusat di Pare-pare Sulawesi Selatan digerakkan terutama oleh pendatang Bugis yang jumlahnya cukup besar. Mereka dikenal sebagai pedagang, petani dan nelayan yang ulet. Disebutkan bahwa tiga pasar tradisional di kota Palu didominasi oleh pedagang Bugis (Arraiyyah, 2002: 322). Peran migran Bugis seperti itu dapat dikembangkan lebih lanjut dengan mengkaji lebih jauh peran mereka dalam mengembangkan pendidikan keagamaan.

Sinergi dan hubungan baik antara migran Bugis dengan penduduk asli setempat di perantauan ditopang oleh nilai-nilai luhur, seperti kemampuan beradaptasi dengan lingkungan. Nilainilai luhur itu tercermin misalnya dalam ungkapan yang menyatakan, Engka pasa' ri lipuku, balanca ri kampo'ku ulanco mabela, ia kia ininnawai kusappa (Ada pasar di negeriku, belanja di kampungku, ku merantau jauh, kendati cinta kasih yang kucari) (Kesuma, 2004: 3). Kemampuan adaptasi orang Bugis tidak terlepas dari nilai-nilai utama yang mereka miliki seperti kecendekiaan dan kejujuran. Nilai-nilai keagamaan orang Bugis dalam kaitannya dengan pendidikan keagamaan dapat dilihat pada pesanpesan keagamaan yang bersifat lisan atau simbolik pada upacara keagamaan yang mereka selenggarakan pada tingkat rumah tangga. Di antaranya, pada upacara mappano lolo (aqiqah), dan takziah. Ceramah takziah yang dihadiri oleh kerabat dan sahabat serta tetangga dari keluarga yang ditimpa musibah kematian biasanya sarat dengan pesan-pesan keagamaan.

\section{Metode Penelitian}

Penelitian ini menggunakan metode kualitatif. Pengumpulan data menggunakan tiga metode, yaitu studi dokumen, pengamatan, dan wawancara. Studi dokumen dilakukan untuk memperoleh data kependudukan, perkumpulan kedaerahan dan anggotanya, data majelis taklim, pengurus lembaga pendidikan keagamaan, guru, dan pihak yang terkait. Di antara dokumen yang dimaksud yaitu Profil dan Data Kantor Kementerian Agama Kota Manokwari, dan Dokumen Dari BPS Kota Manokwari dan Provinsi Papua Barat.

Pengamatan langsung ditujukan terhadap aktivitas ekonomi masyarakat yang menjadi sasaran penelitian. Misalnya, pengamatan dilakukan di pasar tradisional. Pengamatan dilakukan terhadap aktivitas majelis taklim dan aktivitas di tingkat rumah 


\begin{abstract}
tangga yang dipakai untuk menyampaikan pesan-pesan keagamaan atau melakukan transmisi nilai-nilai keagamaan. Informan terdiri dari pejabat pemerintah. Tokoh agama, dan tokoh masyarakat, serta perangkat organisasi KKSS. Wawancara dilakukan dengan menggunakan pedoman. Di samping itu, wawancara diarahkan untuk mengembangkan dan memverifikasi data dan informasi yang diperoleh melalui studi dokumen dan pengamatan. Ketiga metode pengumpulan data diperankan dalam proses triangulasi untuk memastikan akurasi dan keabsahan data yang diperoleh. Data dikelompokkan dalam sejumlah satuan kemudian dipaparkan. Paparan mengacu pada konsep tertentu yang dikemukakan dalam referensi terkait.
\end{abstract}

\section{TEMUAN DAN PEMBAHASAN}

\section{Membaca Angka-Angka Orang Bugis di Papua Barat}

Papua Barat sudah lama dihuni para pendatang. Suku Bugis dan Jawa mendominasi kelompok pendatang. Namun, kedua suku ini memiliki karakter berbeda. Suku Jawa lebih banyak menguasai daerah transmigrasi di pelosok-pelosok, sementara wilayah perkotaan didominasi suku Bugis dan Makassar. Sektor ekonomi dan bisnis yang ada di wilayah Papua juga dikuasai warga Kerukunan Keluarga Sulawesi Selatan (KKSS). Orang Bugis di Papua merupakan pedagang terampil, sehingga berkontribusi besar terhadap perkembangan ekonomi di daerah ini, hingga bertumbuh cepat. Saat ini KKSS dan beberapa tokoh Bugis lainnya, menguasai pusat perdagangan di wilayah Manokwari.
Dari data Statistik yang dirilis BPS dalam Data kelompok Suku Bangsa di Provinsi Papua Barat, yang didasarkan pada hasil sensus penduduk tahun 2010 menunjukkan bahwa: Terdapat sebanyak 40.046 jiwa orang Bugis mendiami daratan Papua Barat, atau sekitar 5,27 persen dari jumlah total penduduk Papua Barat yang mencapai 70.023 jiwa. Kelompok suku Bugis berdasarkan jumlah dan persentase berada pada peringkat terbanyak ke-5 atau masih berada di bawah Papua (387.816 jiwa/51\%), Jawa (111.349/14,64\%), Maluku (78.855/10,37\%), dan Suku asal Sulawesi lainnya $(60.229 / 7,92 \%)$, dari total pemeringkatan 31 kelompok suku bangsa di Papua Barat. Sementara orang Makassar yang juga sering diasosiasikan saling beririsan dengan orang Bugis, berada di peringkat ke-6 dengan jumlah total penduduk 17.025 jiwa atau 2, 24 persen dari total penduduk Papua Barat.

Tentu, angka ini jika dibaca satu arah dan ditafsirkan tunggal akan lebih banyak menunjukkan nilai statistik semata dengan hitung-hitungan jumlah yang tidak begitu signifikan. Namun, jika dilihat secara menyeluruh bahwa jika jumlah Orang yang berasal dari Kelompok Suku Papua (Baca: Orang Asli Papua/OAP) yang hanya 51 Persen saja, artinya bahwa ada 49 persen atau separuh Penduduk Papua Barat adalah Pendatang atau para Migran. Jumlah yang hampir seimbang dengan penduduk tempatan ini potensial mempengaruhi Index pembangunan manusia di tanah Papua, karena telah 'diserbu' oleh arus transmigrasi yang cukup besar.

Sebaran Orang Bugis di Papua Barat Berdasarkan Kabupaten/Kota (Sumber BPS Papua Barat 2010): 


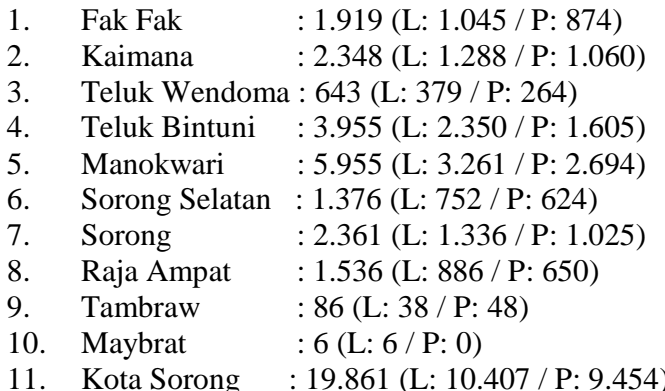

Orang Bugis di Papua Barat jika dilihat dari persebarannya berdasarkan agama, maka dapat dilihat secara kuantitatif angka yang cukup menarik, terlebih jika melihat kecenderungan utama agama orang Bugis di tempat asal yang sangat identik dengan Islam. Catatan sejarah (Mattulada, 1998: 154) menunjukkan seluruh tanah Bugis sudah menerima Islam sejak 1612. Catatan lainnya menyebutkan bahwa, sebelum kerajaan-kerajaan Bugis menerima Islam, antara tahun 1603-1611, orang Bugis pada umumnya telah menganut kepercayaan terhadap Dewata Seuwae (Dewa yang Tunggal), To Palanroe (Khalik), dan Patotoqe (Penentu Nasib), sebuah bentuk kepercayaan yang berasal dari zaman La Galigo (Mattulada, 1983: 229-230).

Semenjak menerima Islam pada abad ke 17 itulah, orang Bugis bersama dengan orang Aceh dan Minangkabau di Sumatera, orang Melayu, Kalimantan, dan Malaysia, orang Sunda, serta orang Madura dipandang sebagai orang Nusantara yang kuat keislamannya (Pelras, 2006: 4). Bahkan orang Bugis menjadikan agama Islam sebagai bagian integral dan esensial dari Pangngaderreng (Mattulada, 1985: 275-227). Oleh karena itu Islam dan masyarakat Bugis adalah sesuatu hal yang tidak bisa dipisahkan (Akhmar 2018) $\begin{array}{ccc}\text { Maka, } & \text { pranata } & \text { yang } \\ \text { dipraktikkan di masyarakat Bugis }\end{array}$ selalu bersendikan pada ajaran Islam. Sementara ada yang dipegang sebelumnya tetap dipertahankan jikalau itu tidak bertentangan dengan teologi Islam. Keterbukaan untuk menerima perkembangan terbaru senantiasa tumbuh. Sekaligus memegang teguh kesadaran masa lalu. Penggabungan di antara keduanya menjadi sebuah karakter tersendiri dimana teguh memegang tradisi tetapi pada saat yang sama menerima dan mau membuka diri terhadap hal-hal yang menjadi tuntutan keadaan. Karakteristik ini terbentuk karena adanya kesamaan antara prinsip keislaman dengan kebudayaan yang sudah dipraktikkan sebelum datangnya Islam. Demikian pula kesediaan untuk menjadikan Islam sebagai satu-satunya pedoman yang harus dilaksanakan.

Namun begitu, dalam konteks Papua Barat, terdapat statistik yang cukup mencengangkan ketika membaca sebaran keagamaan orang Bugis di Papua Barat. Berdasarkan data statistik Kelompok Suku Bangsa di Papua Barat tahun 2010 yang dirilis oleh BPS Papua Barat, mengelompokkan jumlah penduduk menurut suku bangsa dan agama. Dari total 40.046 jiwa orang Bugis mendiami daratan Papua Barat, 631 orang diantaranya tercatat beragama Kristen, 100 orang Katolik, dan 1 orang beragama Hindu. Ini berarti, dari total jumlah penduduk yang mengaku Bugis, 1,83 persen di antaranya tidak menganut Agama Islam. Angka ini terbilang mengejutkan mengingat kecenderungan keberagamaan orang Bugis adalah Islam, bahkan Islam dan orang Bugis adalah satu garis lurus dengan satu tarikan nafas yang tidak bisa dipisahkan. 
Tentu, angka ini meskipun secara kuantitas tidaklah banyak, namun penting untuk diperhatikan, atau setidaknya tidak diabaikan sebagai identitas keagamaan yang 'baru' bagi orang Bugis.

Tentu, angka ini perlu diverifikasi, meskipun menjadi satusatunya data resmi yang dirilis oleh BPS terkait keberagamaan suku Bugis di tanah rantau. Hanya saja, dalam beberapa catatan wawancara dengan tokoh Muslim Bugis di Manokwari, cukup terkejut dengan jumlah yang sedemikian besar, namun di saat bersamaan juga tidak bisa memungkiri bahwa ada beberapa saudara-saudara Pasompe Ogi di Papua Barat yang secara sadar memilih pindah agama, karena berbagai faktor. Salah satu yang cukup mencolok adalah perkawinan antara orang Bugis dengan masyarakat lokal Papua, yang terkadang menghendaki persyaratan pindah agama sebagai salah satu yang harus dipenuhi.

Hal lainnya adalah faktor ekonomi, yang membuat beberapa di antara orang Bugis di tanah Papua terpaksa pindah agama demi mendapat jaminan kesejahteraan hidup. Hal-hal semacam itu, tentu tidak bisa dicegah oleh siapa pun karena merupakan pilihan personal orang-orang tersebut, namun cukup menjadi catatan lain dalam pengembangan Pendidikan keagamaan Islam oleh orang Bugis di tanah rantau, untuk lebih dimaksimalkan dakwah kultural kaitannya dengan penguatan akidah.

Di sisi lain, meskipun akhirnya ada di antara saudara-saudara Bugis kita di tanah Papua yang kemudian memilih pindah agama secara sadar dari Islam ke agama Kristen dan Katolik, ternyata ada juga di antara orang-orang Migran asal Toraja, Manado, bahkan Orang Asli Papua yang akhirnya memilih menjadi mualaf, dan berkeinginan memeluk agama Islam secara sadar. Beberapa diantaranya, mendapat hidayah setelah mengikuti dan mencermati dakwah keagamaan Islam yang sangat kooperatif dan menjunjung tinggi nilainilai kemanusiaan.

\section{Fragmen Bugis Papua}

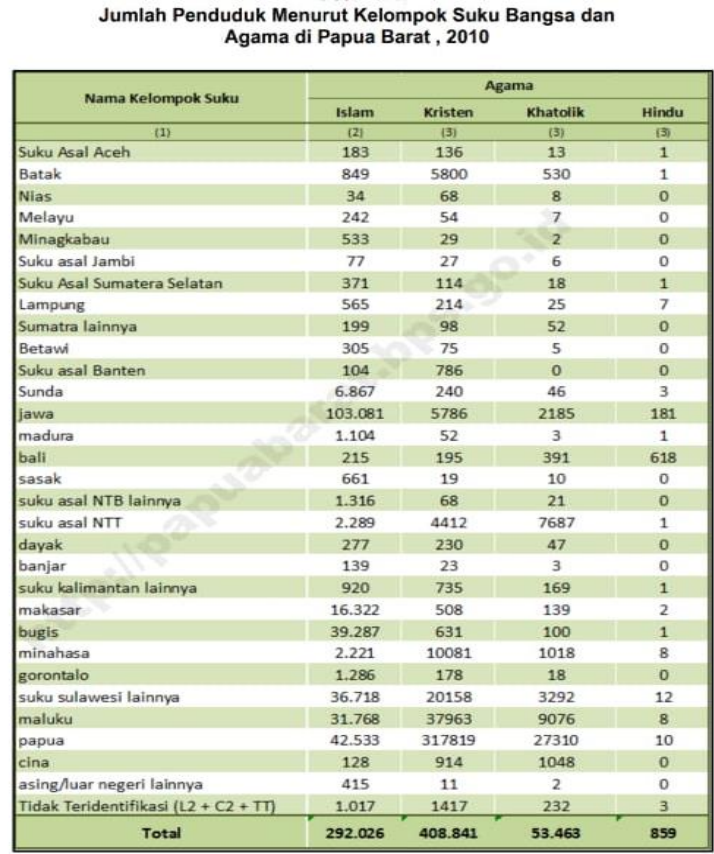

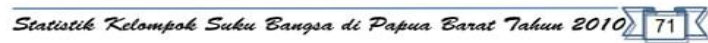

Keberadaan masyarakat Bugis yang berpindah ke Papua tidaklah terjadi hanya karena sekarang saja. Beberapa diantaranya sudah bermukim sejak kelahiran. Walaupun demikian mereka masih saja berusaha mempertahankan identitas dan juga hubungan emosional dengan leluhur mereka. Namun demikian mereka sudah berinteraksi dengan masyarakat setempat kemudian menjelma menjadi sebuah identitas baru. Tidak hanya Bugis tetapi Bugis Papua. 
Segala atribut kehidupan yang disandangnya menjadi bagian yang tidak terpisahkan dengan keadaan Papua itu sendiri. Mereka kemudian mengidentifikasi diri tetap sebagai orang Bugis, namun dengan keberadaan mereka di Papua secara khusus kemudian menyebut diri dengan Bugis Papua. Sekaligus ini menjadi sebuah lambang bahwa Papua sudah menjadi bagian yang tidak terpisahkan dari identitas yang mereka miliki (Wekke 2017).

"Bugis Papua", yang merupakan bentuk khusus penetapan komunitas Bugis yang datang, lahir, besar, dan menetap di Papua. Bahkan beberapa diantaranya sudah dianggap sebagai keluarga adat setelah melalui dialektika sosiologis yang cukup lama. Bugis Papua juga mewakili persentase hampir dua persen penduduk Bugis yang beragama non Islam di tanah Papua. Hal ini dimungkinkan karena beberapa hal antara lain: (1) menikah dengan orang asli Papua, umumnya jika sang Bugis adalah perempuan, sangat memungkinkan mengikuti segala bentuk kultur suaminya, bahkan beberapa catatan menunjukkan perpindahan agama perempuan Bugis setelah menikah dengan orang asli Papua.

Keturunan mereka inilah yang kemudian lebih dikenal dengan Bugis Papua. (2) Bugis Papua dapat dilihat dari korelasi alamiah orang-orang Bugis yang sudah menetap di Papua dalam rentan waktu yang cukup lama, bahkan secara aksen dan karakteristik fisik dan komunikasi lebih mencerminkan karakter ke-papuaan, yang tidak menggerus jiwa kebugisannya, garis darahnya masih bisa dilacak secara pasti bahwa yang bersangkutan adalah keturunan Bugis.
Untuk kepentingan internal masyarakat Bugis kemudian mengorganisasikan diri dalam Kerukunan Keluarga Sulawesi Selatan (KKSS). Namun organisasi ini berdiri tidak saja di Papua tetapi di Indonesia. Bahkan dipimpin langsung dengan sekretariat tetap di Jakarta. Sehingga untuk menjelaskan kesatuan masyarakat Bugis di pandangan dari KKSS tidak saja terjadi di Papua tetapi sudah berada dalam konteks nasional. Keberadaan KKSS tidak lebih dari sebuah organisasi paguyuban saja untuk silaturahmi. Sementara itu pelbagai ragam latar belakang politik, profesi, dan aktivitas sosial anggotanya melebur dalam organisasi yang dibangun untuk kepentingan kekeluargaan semata. Organisasi ini hadir secara nasional, sehingga tidak dapat dijadikan sebagai sebuah bentuk pengorganisasian karena latar belakang Papua. Hanya saja, dengan organisasi ini yang ditopang oleh pilar masingmasing daerah sehingga membentuk keakraban, perkenalan, dan hubungan pertemanan yang tidak saja berupa kekerabatan emosional tetapi menjadi kerja sama yang rasional.

Hubungan dengan tanah leluhur hanyalah semata-mata dalam aspek emosional. Tidak lagi berkeinginan untuk kembali. Sementara ketika wafat, maka memilih untuk dikuburkan di tanah rantau. Justru tanah rantaulah yang menjadi tanah air mereka. Tidak lagi kemudian harus membebani keluarga untuk mengurus mayatnya dan mengembalikan itu ke tanah Bugis. Justru ketika berada di rantau itulah, tanah dimana mereka membangun kehidupan yang sudah disebut sebagai tanah air walaupun itu bukan tanah kelahiran. Maka, totalitas kehidupan yang dijalankan sepenuhnya 
dicurahkan untuk wilayah yang didiami. Tidak lagi mengedepankan aspek keturunan tetapi justru membangun untuk kehidupan masa depan. Dimana keturunan berikutnya akan memperoleh sumber kehidupan dari yang ditempati sekarang ini (Wekke 2017).

Kondisi semacam ini kemudian menjadikan sebagian besar orang Bugis yang akhirnya memilih merantau ke tanah Papua menjadi sedemikian leburnya dengan kondisi di Tanah Papua, menyangkut dialek, cara bertutur, sistem dan pola hidup, serta dimensi kebudayaan Papua dicerap dengan cukup mendalam. Beberapa di antaranya bahkan telah kawin mawin dengan penduduk setempat. Hal demikian pada gilirannya menjadikan jarak sosial antara orang Asli Papua, dengan pendatang asal Bugis yang memilih menetap di Manokwari menjadi semakin tipis, atau boleh dikata, tak berjarak lagi. Kemampuan adaptasi seperti ini kemudian dalam beberapa hal pada gilirannya dapat membentuk sebuah identitas kebugisan yang baru, yakni Bugis-Papua, dimana terjadi penggabungan kebudayaan dan kebiasaan tempatan antara karakteristik Bugis dengan karakter Papua dalam individu yang saling melengkapi.

Pada saat-saat tertentu, mereka yang memiliki adaptasi yang sangat spesifik seperti ini, kemudian menjadi sangat berperan kalau-kalau ada gesekan antara komunitas Bugis di Kampung Makassar dan Kampung Bugis, dengan masyarakat lokal yang notabene orang Asli Papua, sebagai mediator, dan atau juru bicara perdamaian satu sama lain. Praktik semacam ini bisa dilihat misalnya dalam penyelesaian kasus protes pembangunan Masjid Rahmatan Lil
Alamin di Andai yang dimotori oleh Haji Appe, oleh orang Asli Papua yang mengatasnamakan zending, akhirnya bisa ditengahi dengan baik melibatkan tokoh adat, dan Bugis Papua sekaliber H. Nurjaya. "Kita di sini Alhamdulillah sudah dianggap bagian dari mereka. Dalam beberapa kesempatan, kita juga harus dan tidak boleh menutup mata jika sedang ada pembangunan gereja. Semua harus dibantu, itu adalah investasi kepercayaan yang mesti kita tanamkan demi mendapat simpati. Tentu hal itu kita lakukan, bukan bermaksud untuk mengharapkan perlakuan yang sama ketika kita membangun Masjid, namun setidaknya kita tidak dihalang-halangi. Bagi kami, dimana ada rumah ibadah didirikan, di situ akan ada banyak doa-doa dipanjatkan. Dengan begitu, berkah dan kedamaian senantiasa diberikan Tuhan secara berkesinambungan di Tanah Papua yang kita cintai ini". (H. Nurjaya, Ketua DPW KKSS Papua Barat)

Dari sinilah dapat dilihat bahwa konteks pemberdayaan komunitas oleh orang-orang Bugis yang notabene sebagai pendatang di tanah Papua tidak terlihat cukup kendala yang dihadapi. Hal ini karena dalam banyak hal kekuatan memainkan pola komunikasi yang merupakan domain "cappa lila", atau kekuatan komunikatif orang Bugis tidak hanya dalam aspek berbicara dan berkomunikasi verbal dengan orang Papua, namun juga dalam mengadaptasi norma-norma yang berlaku di tanah Papua. Kepekaan sosial terhadap karakteristik Manokwari yang identik dengan kota Injil, mampu diadaptasi dengan baik dengan turut serta dalam membantu pembangunan gereja. 
Di sinilah keberhasilan para perantau Bugis dalam menyentuh ruang sakral orang-orang Papua, serta masuk lebih dalam pada kesatuan dan kepaduan sistem dan budaya setempat, sehingga penolakan terhadap orang Bugis (sebagai pendatang), dapat diminimalkan. Hal ini sekaligus sebagai penegasan terhadap perspektif pemberdayaan masyarakat yang sedemikian baik dimainkan oleh orangorang Bugis dalam melakukan dialektika pemberdayaan dan pengembangan komunitas (Rukminto Adi, 2008).

\section{Orang Bugis Papua dan Pendidikan Keagamaan}

Berikut adalah tempat yang diidentifikasi/berhasil dihimpun (berdasarkan hasil pembacaan dan wawancara pelbagai sumber) memiliki kantong-kantong lokasi pemukiman orang Bugis di Manokwari, beberapa di antaranya mengelompok dan menguasai satu Desa, atau Kelurahan, minimal setingkat RT, namun beberapa lainnya hidup terpisah, namun tetap menjalin komunikasi dalam bentuk pertemuan-pertemuan maupun dalam urusan bisnis dan perdagangan. Tempat itu dapat diindentifikasi pada (1) Kampung Makassar, (2) Kampung Bugis, dan (3) Andai.

Pada prinsipnya, sistem pengembangan Pendidikan keagamaan di Manokwari dapat dipetakan dalam dua aspek, yakni pengembangan Pendidikan keagamaan by Person dan Pengembangan Pendidikan Keagamaan by Community. Pemetaan ini tidak terlepas dari pembagian peran dari para Migran Bugis ini menurut 3 corak peran yang dikembangkan yakni sebagai Fasilitator, Motivator, dan atau sebagai eksekutor pengembangan
Pendidikan keagamaan di tanah rantau. Tidak dapat dipungkiri bahwa peran tokoh tertentu sebagai penggerak dan fasilitator adalah corak yang paling menonjol di Manokwari. Hal ini karena para migran Bugis di Manokwari lebih banyak mendedikasikan dirinya di bidang Ekonomi, Pertanian dan aspek Laut. Mereka umumnya menguasai pasar, pekerja proyek, dan penyuplai makanan dari hasil tangkapan laut.

Tokoh-tokoh Bugis dengan nama besar di Manokwari sekaligus juga merupakan tokoh yang disegani di Papua Barat, semisal Haji Nurjaya, Haji Appe, dan Haji Baharuddin Sabola adalah penggerak utama pengembangan keagamaan di Manokwari. Mereka juga adalah tokoh penting dalam Kerukunan Keluarga Sulawesi Selatan di Papua Barat. Dari tiga nama besar itu, khusus untuk Haji Nurjaya lebih banyak sebagai motivator dan fasilitator karena kekuatan modal dan kewibawaan, serta pengaruh yang dimilikinya, sehingga segala pengembangan dakwah keagamaan Islam di Manokwari, dan Papua Barat secara umum, beliau selalu memberi support baik secara moril maupun materiil.

Hajji Appe, juga memiliki fungsi dan peran yang relatif sangat penting, karena beliau selain memiliki kemampuan finansial yang sangat besar, juga sekaligus mendedikasikan dirinya terjun langsung dalam dakwah keagamaan Islam melalui Jamaah Tablig. Bahkan beliau mendirikan Masjid Mewah dan megah di atas 30 hektar tanahnya sebagai pusat dakwah dan pengembangan keagamaan Islam. Di Masjid itu, yang terletak di Andai juga sekaligus digunakan sebagai pusat Lembaga Tahfiz Quran dengan mengajak serta tokoh muda Bugis yang 
memiliki kemampuan pemahaman keislaman yang mumpuni yakni Maulana Sofyan. Di sanalah pusat tahfiz Alquran dilakukan, serta potensial menjadi pesantren yang lebih fungsional.

Masih di Andai, terdapat cabang Pesantren Hidayatullah Manokwari yang tokoh dan para ustaznya juga berasal dari Bugis. Sangat dimaklumi karena pusat Pesantren Hidayatullah di Gunung Tembak Balikpapan adalah Pesantren yang didirikan oleh Tokoh Bugis Asal Sinjai bernama Ustaz Abdullah Said, sehingga corak pesantren dan keagamaan yang dikembangkan identik dengan pola yang dikembangkan di Gunung Tembak.

Sosok lainnya adalah Haji Baharuddin Sabola, tokoh Bugis alumni DDI Mangkoso yang diajak ke Manokwari oleh Haji Nurjaya untuk mengambil peran kerohanian Islam. Beliau tercatat sangat Aktif di Majelis Ulama Indonesia Papua Barat, FKUB Papua Barat, Badan Amil Zakat Papua Barat, dan tokoh pendakwah yang sangat dikenal di seantero Manokwari bahkan Papua Barat.

Pusat

Pengembangan

Pendidikan keagamaan lainnya juga dapat dijumpai di Masjid Attaqwa Kampung Makassar sebagai pusat pengajian Islam yang diikuti oleh jamaah yang 90 persennya adalah orang Bugis. Di Kampung Makassar inilah sebenarnya asal dari pesatnya Jemaah Tablig yang digawangi oleh Haji Appe tumbuh dan berkembang, sebelum Masjid di Andai dibangun untuk dijadikan sebagai pusat Tahfidz alquran dan tablig Islam rutin dilakukan, sebelum akhirnya berpindah ke Masjid Rahmatan Lil Alamin di Andai.
Selain di Kampung Makassar, Masjid Madinah di bilangan jalan Belibis Kompleks Bugis Wosi Manokwari, juga menjadi pusat pengembangan keagamaan masyarakat migran Bugis di Kota Manokwari Papua Barat. Jika di Masjid Attaqwa yang dulunya menjadi 'rumah' bagi para jamaah tablig, maka di Masjid Madinah, sedikit banyaknya dimanfaatkan oleh Wahdah Islamiyah sebagai tempat melangsungkan pengajian tentu setelah mendapat izin dari warga setempat. Namun, posisi ormas Islam tertentu menjadi suatu hal yang dimaklumi satu sama lain oleh para Jemaah yang juga berasal dari lingkungan sekitar Kampung Bugis, sebab bagi mereka yang memang rutinitasnya lebih banyak bergerak di sektor ekonomi, persoalan dakwah keagamaan dan memakmurkan masjid adalah tugas bersama-sama, namun jika ada ormas dan atau kelompok keagamaan tertentu yang ingin memotori kegiatan kerohanian, tentu tetap akan disambut baik, sepanjang asa-asa kooperatif selalu dijunjung tinggi (Wawancara Baharuddin Sabola, Manokwari).

Selain itu, peran serta aktif masyarakat Bugis dengan menempatkan tokoh-tokohnya sebagai agamawan dan atau tokoh agama yang turut mengambil posisi pada wilayahwilayah vital di Manokwari, bahkan di tingkat Provinsi Papua Barat semacam Badan Amil Zakat dan Majelis Ulama Indonesia, menjadi pranata kelembagaan Islam yang menghendaki ketokohan dan pengabdian dari orangorang Bugis di Manokwari, tentu bersama-sama dengan tokoh Islam dari Suku lainnya yang notabene mereka pun mayoritas pendatang, seperti dari Jawa, dan Maluku. 
Konsistensi melaksanakan kegiatan keagamaan, seperti mengisi dakwah Keislaman pada mimbar-mimbar masjid menjadi salah satu medium pengembangan dan aktualisasi diri masyarakat Bugis di Manokwari. Selain karena tuntunan agama, secara sosial, mereka merasa terpanggil untuk mengambil bagian dalam memberi bekal hidup dan keagamaan bagi warga Muslim di Papua Barat, termasuk mereka para perantau Bugis lainnya, bahkan juga mengajak suku suku lain selain bugis.

Hal lain, yang juga menopang pengembangan Pendidikan keagamaan Islam orang-orang Bugis di Manokwari adalah dengan turut serta dalam Lembaga Pendidikan Formal seperti YAPIS (Yayasan Pendidikan Islam) cabang Manokwari, dimana secara sukarela dan dengan pengabdian yang tidak main-main, ditunjukkan oleh sosok hartawan, dermawan, dan agamawan seperti Haji Nurjaya, dalam menggawangi segala aspek pengembangan Pendidikan di bawah YAPIS. Selain mendermakan harta dan jiwanya, Pak Haji Nurjaya juga sekaligus mengajak kolega-kolega Bugis lainnya untuk menjadi pengajar di Yayasan yang dipimpinnya itu.

Pesantren dan Lembaga Tahfidz adalah bagian integral yang pada akhirnya juga menjadi perhatian besar para migran Bugis yang memiliki rezeki yang cukup untuk membantu dan menginisiasi pembangunan Pesantren di Manokwari. Seperti Pesantren Hidayatullah, Pesantren Nurul Jannah, dan Lembaga Tahfidz Rahmatan Lil Alamin pimpinan Haji Appe di Andai, serta Rumah Tahfidz Robbaniyah Reremi Pemda yang dikelola oleh Wahdah Islamiyah Manokwari. Selain itu, pengelolaan
Madrasah Diniyah juga menjadi hal lainnya yang diperjuangkan. Sebut saja misalnya Sanggar Anak Saleh Madrasah Diniyah Ridwanul Bahri Manokwari, dimana melibatkan tokoh Bugis seperti H. Baharuddin Sabola, yang juga dapat dikategorikan sebagai Tokoh Bugis yang sudah sangat kental ke-papuaannya. Di tangannya, kemajuan Madrasah Diniyah Ridwanul Bahri menjadi niscaya. Karena ketokohan dan nama besarnya sebagai mubalig dan tokoh Islam.

\section{Masjid: Tempat Segala Asa dan Hajat Hidup Diperbincangkan}

Masjid menjadi sebuah tempat untuk mewujudkan harapan-harapan bagi para perantau. Dalam kaitan ini, masyarakat Bugis menjadikan masjid sebagai sarana untuk berdialog, bertemu, dan berinteraksi dengan masyarakat lain. Dengan tidak mengajukan pemahamannya dalam praktik keislaman, mereka senantiasa bergabung dengan kelompok yang lebih besar. Kecuali jika dalam lingkungan itu mereka membangun masjid bersama dengan kelompok masyarakat sendiri, maka pelaksanaan ibadah disesuaikan dengan tradisi masing-masing.

Masjid juga menjadi perjumpaan pelbagai kalangan. Dengan identitas keislaman yang menyatukan, mereka kemudian memilih menjadi bagian dari masyarakat Islam yang majemuk dengan paham dan mazhab yang berbeda-beda. Namun demikian, selalu berusaha untuk turut berkontribusi dan memberikan bantuan dalam bentuk pendanaan maupun sumbangan dalam penyelenggaraan kegiatan-kegiatan yang dilaksanakan di masjid secara berkala. Dalam kondisi seperti ini, agama menjadi faktor 
perekat dan tidak lagi mementingkan basis suku dan etnisitas (Lacroiz and Monnier 2015).

Di Kota Injil Manokwari, masjid menjadi objek vital yang senantiasa menjadi tempat perbincangan segala hal, baik soal agama, hajat hidup, bahkan problematik sosial kemasyarakatan lainnya, khususnya bagi masyarakat Islam yang sebagian besarnya adalah perantau. Tentu saja, menjadikan masjid sebagai ruang diskusi dan bertukar pikiran adalah sesuatu yang mampu membangkitkan romantisme kampung halaman, tidak terkecuali oleh orang-orang Bugis di Manokwari. Di dalam dan di halaman masjid juga sekaligus sebagai tempat paling bersahaja bagi siapa saja yang datang. Tidak hanya untuk beribadah, masjid juga sebagai tempat sejuk melepas kepenatan dari aktivitas yang dilakukan sepanjang hari.

Bagi orang Bugis, tercatat beberapa Masjid sebagai pusat berkumpul dan melakukan kegiatan. Sebut saja Masjid At Taqwa Kampung Makassar, Masjid Madinah di Kompleks Bugis, Masjid Ridwanul Bahri Wosi, sampai Masjid Rahmatan Lil Alamin di Andai. Serta masjidmasjid lainnya yang bahkan dalam pembangunannya tidak lepas dari kontribusi moril dan materil dari warga Muslim pendatang di Manokwari.

Di Masjid At Taqwa Kampung Makassar, dulunya adalah pusat dakwah para Jamaah Tabligh di Kota Manokwari, yang mayoritas jemaahnya adalah orang Bugis, Jawa, dan Maluku, serta orang asli Papua beragama Islam. Letaknya yang strategis dan cukup luas menjadikannya sebagai tempat berkumpul yang cukup lapang. Majelis Kajian Keagamaan, Majelis Taklim, serta dakwah Keagamaan Islam banyak dipusatkan di sini. Tidak hanya itu, rapat-rapat juga sering kali dilakukan di Masjid ini, khususnya bagi Organisasi Pilar dari KKSS yang sering menjadikannya sebagai tempat konsolidasi. Bahkan yang sedikit ekstrem, masjid At Taqwa sering dijadikan pusat bertemu orang-orang Bugis-Makassar ketika terlibat masalah dengan warga lokal.

Selain itu, masjid Madinah di Kampung Bugis juga menjadi pusat konsentrasi pengembangan dan pertemuan gagasan para perantau Bugis-Makassar di Manokwari. Selain itu, masjid Ridwanul Bahri yang merupakan masjid yang diasosiasikan dengan TNI Makowari, juga kerap kali dijadikan pusat berkumpul dan berdiskusi antara para perantau Bugis. Khususnya di sela-sela Shalat 5 waktu, terutama di hari Jumat. Di Masjid ini, juga kerap menjadi sarana lobby-lobby bisnis orang Bugis yang memang memegang peran yang cukup besar di Manokwari khususnya di bidang Infrastruktur. Masjid ini juga menjadi pusat pengembangan dakwah, serta terdapat Madrasah Diniyah yang fungsional. Beberapa tokoh penting KKSS kerap terlihat di masjid ini. Bahkan beberapa janji ketemu dengan tokoh-tokoh penting KKSS sering dilakukan di Masjid ini.

Penyediaan sarana dan prasarana serta pembangunan masjid di Manokwari, bahkan di Papua Barat adalah bagian penting dalam pengembangan dakwah keagamaan Islam yang bagi orang-orang Bugis berpengaruh dijadikan sebagai lading amal dengan mendermakan hartanya dalam pembangunan Masjid. Tentu, membangun masjid di Kota Manokwari yang dikenal dengan jargon Kota Injil 
tidaklah mudah, selain aturan resmi melalui SKB 2 Menteri perihal syarat dan ketentuan pembangunan rumah ibadah yang menghendaki persetujuan dari warga sekitar, yang notabene agak sulit jika melihat lokasi masjid yang terletak di daerah yang tingkat heterogenitas pemeluk agamanya cukup tinggi. Status tanah tempat masjid ingin didirikan juga harus sudah clear dengan segala macam indoktrinasi, baik itu tanah ulayat, tanah adat, sampai tanah zending milik gereja.

Sehingga, diperlukan pendekatan multi persuasif untuk dapat benar-benar mendapatkan ijin pembangunan Masjid di tanah Manokwari, tempat dimana Injil pertama kali dikabarkan di tanah Papua oleh Otto-dan Geisler puluhan tahun silam, sehingga menjadikannya sebagai kota Injil di tanah Papua.

Di sini, sebenarnya membangun masjid itu tidaklah rumit, apalagi soal biaya Insya Allah tersedia. Namun yang penting untuk diperhatikan adalah, masalah dengan warga setempat terlebih dahulu harus clear, khususnya jika itu tanah adat, atau bahkan dekat dengan tanah zending. Namun Alhamdulillah jika kita bisa bicarakan baik-baik dengan pihak adat dan gereja, masalah dapat teratasi. Meski dengan perjuangan dan pola komunikasi yang harus dirawat lama. Sebab kita-kita ini Alhamdulillah sudah dianggap bagian dari mereka. Dalam beberapa kesempatan, kita juga harus dan tidak boleh menutup mata jika sedang ada pembangunan gereja. Semua harus dibantu, itu adalah investasi kepercayaan yang mesti kita tanamkan demi mendapat simpati. Tentu hal itu kita lakukan, bukan bermaksud untuk mengharapkan perlakuan yang sama ketika kita membangun Masjid, namun setidaknya kita tidak dihalang-halangi. Bagi kami, dimana ada rumah ibadah didirikan, di situ akan ada banyak doa-doa dipanjatkan. Dengan begitu, berkah dan kedamaian senantiasa diberikan Tuhan secara berkesinambungan di Tanah Papua yang kita cintai ini. (Wawancara H. Nurjaya, Ketua DPW KKSS Papua Barat, 24 Maret 2019).

\section{Safari Ramadhan: Dakwah Kultural ala KKSS Papua Barat}

Masih ada salah satu program yang menjadi bagian integral eksistensi dan peran keagamaan orang Bugis di Papua Barat secara umum, dan Manokwari secara khusus. Program ini adalah Safari Ramadhan dengan bentuk yang sangat khas. Dimotori oleh KKSS secara kelembagaan, para perantau Bugis-Makassar yang tergabung dalam komunitas Kerukunan Keluarga Sulawesi Selatan, melakukan Safari Ramadhan keliling Provinsi Papua Barat dalam rangka melakukan dakwah keagamaan, sekaligus menyalurkan bantuan-bantuan langsung, baik berupa sembako, Alquran, Pakaian, Sandang, Pangan, sampai pada bantuan Pembangunan Masjid, dilakukan selama Bulan Ramadhan.

Kegiatan yang telah rutin dilakukan, setidaknya selama 8 tahun terakhir ini adalah cara KKSS menyampaikan dakwah Bil Hikmah yang mendatangi pulau-pulau terpencil, daerah-daerah pelosok Papua Barat untuk bersafari Ramadhan. Program ini juga merupakan program kerja KKSS bidang Dakwah dan Kerohanian, yang dipimpin langsung oleh Ketua DPW KKSS Bapak H. Nurjaya.

Kegiatan yang pertama kali dilakukan sejak 2011 lalu adalah 
inisiasi dari pengurus KKSS dengan mendatangi pelosok-pelosok Papua Barat, yang agenda utamanya adalah silaturahmi. Tentu untuk menjangkau daerah yang sangat terpencil dengan medan yang teramat sulit, bahkan harus melewati laut, dan pegunungan membuat tim yang diikutsertakan haruslah mereka yang memiliki semangat keikhlasan, dan jiwa yang tangguh demi mengarungi medan berat, terlebih dilakukan di bulan Ramadhan, dan seluruhnya menjalankan ibadah puasa.

Kegiatan yang dilakukan ini murni merupakan swadaya dari masyarakat KKSS, dan seluruh umat Islam di Manokwari yang bersedia memberikan donasi, 80 persen anggaran ditalangi oleh $\mathrm{H}$. Nurjaya. Baginya, Safari Ramadhan adalah jalan silaturahmi yang tentu dapat mendekatkan setiap individu dengan individu lainnya, menyalurkan berkahberkah Allah SWT, kepada orangorang dan melakukan edukasi keagamaan dalam bentuk dakwah dan pengembangan keagamaan. Tim yang terlibat terdiri atas orang-orang yang memiliki dedikasi dan bersedia mengarungi kerasnya medan.

Program Safari Ramadhan yang memang langsung menyentuh warga Muslim di Pelosok juga mendapat apresiasi yang sangat besar dari Pemerintah Papua Barat, dalam sambutannya pada pelepasan tim Safari Ramadhan tahun 2018 yang lalu, Gubernur Papua Barat Dominggus Mandacan mengatakan bahwa apa yang dilakukan oleh KKSS ini, selain berorientasi kemanusiaan juga merupakan pola pengembangan saling membantu satu sama lain, yang kemudian dapat mempererat persatuan dan kesatuan kita di Papua Barat.
"Mereka adalah para relawan/mujahid kami yang mempertaruhkan nyawanya demi kemajuan masyarakat muslim di pedalaman pesisir Papua Barat. Mereka melakukan safari dakwah ke berbagai pelosok di Papua".

Para aktivis di DPW Kerukunan Keluarga Sulawesi Selatan (KKSS) Papua Barat melepas Safari Dakwah yang ditempuh dengan perjalanan darat, laut, dan sungai ke pedalaman Papua. Mereka membawa zakat, infak, dan Sadakah umat muslim berupa sembako, pakaian, Al-Quran, dan berbagai sumbangan lainnya. Gerakan dakwah Safari Ramadhan KKSS Papua Barat yang sekarang sudah memasuki tahun yang kedelapan merupakan Napak tilas dakwah yang pernah dilakukan oleh Syekh Yusuf AlMakassar yang menyebarkan Islam selain di Nusantara juga Asia Tenggara, bahkan hingga Afrika Selatan. "Kini kami di KKSS berdakwah di pesisir Papua Barat. Memang semenjak zaman dahulu kala, sejarah mencatat ajaran Islam telah menjajaki Papua pada Abad XVI terutama di pantai barat dan selatan. Namun tidak berjalan mulus karena buas dan beratnya medan tanah Papua saat itu” (H. Nurjaya, Ketua KKSS Papua Barat).

\section{PENUTUP}

Pengembangan keagamaan Islam di tanah Papua, khususnya di Kota Injil Manokwari cukup banyak diwarnai oleh para perantau Bugis yang bekerja sama dengan para pendatang Muslim lainnya, seperti Jawa dan juga Maluku. Pola adaptasi yang dikembangkan, sangat peka terhadap prinsip-prinsip norma yang berlaku pada masyarakat setempat. Hal ini adalah modal baik bagi Orang Bugis- 
Papua dalam mengembangkan pola keberagamaan yang Islami, adaptif, dan komunikatif. Sehingga penerimaan orang-orang lokal menjadi sesuatu hal yang niscaya.

Orang Bugis Papua Barat, khususnya di Kota Manokwari adalah mereka yang banyak bergerak di bidang perdagangan, dan pengembangan infrastruktur, yang lebih berorientasi ekonomi. Di sisi lain, keberhasilan di bidang ekonomi itu berdampak positif dalam pengembangan keagamaan Islam. Orang Bugis-Papua di Manokwari adalah Fasilitator, Motivator, dan sekaligus eksekutor dalam pembinaan keagamaan, dalam hal ini, mereka adalah penyandang dananya, penggerak komunitas, sampai hal-hal teknis berupa pengisian ruang keagamaan Islam baik dalam hal dakwah, Pendidikan keagamaan formal dan nonformal juga dilakukan dengan totalitas, dan kebersamaan yang terjalin kuat, di tanah rantau.

Oleh karena itu, kekuatan pengaruh dan komitmen kuat dari perantau Bugis di tanah Papua dalam pengembangan keagamaan ini perlu didukung dari berbagai aspek, salah satu diantaranya adalah dengan mempertemukan keseriusan dan totalitas orang Bugis ini dengan orangorang yang memiliki keunggulan dalam pemahaman keagamaan, yang dapat berasal dari para ulama, alumni pesantren dan perguruan tinggi Islam, serta mubalig dari seantero negeri, dapat bersama-sama menyukseskan program Pendidikan keagamaan yang sudah dilakukan agar lebih berbobot. Hal lain adalah suplai buku-buku keagamaan yang otoritatif sangat dibutuhkan, untuk memperkaya khazanah keagamaan di tanah Papua.

\section{DAFTAR PUSTAKA}

Abidin, Andi Zainal. 1983. Persepsi Orang Bugis-Makassar Tentang Hukum, Negara Dan Dunia Luar. Bandung: Penerbit Alumni.

Akhmar, Andi Muhammad. 2018. Islamisasi Bugis: Kajian Sastra Atas La Galigo Versi Bottinna I La Dewata Sibawa I We Attaweq. Jakarta: Yayasan Pustaka Obor Indonesia.

Ammarell, Gene. 2002. "Bugis Migration and Modes of Adaptation to Local Situstions." Journal Ethnology 41 (1):51-67.

-. 2016. Bugis Navigation. Diterjemahkan Oleh Nurhady Sirimorok Dengan Judul "Navigasi Bugis." Cet. I. Makassar: Penerbit Ininnawa.

Andaya, Leonard Y. 1995. "The BugisMakassar Diasporas." JMBRAS 68.

Arraiyyah, M. Hamdar. 2002. "Peta Kerukunan Umat Beragama Propinsi Sulawesi Tengah." In Riuh Di Beranda Satu: Peta Kerukunan Umat Beragama Di Indonesia, Seri II, edited by Achmad; Syahid and Zainudin; Daulay. Jakarta: Puslitbang Kehidupan Beragama.

Elisabeth, A, M.S Widjojo, R Cahyadi, and Blegur. 2004. "Pemetaan Peran \& Kepentingan Para Aktor Dalam Konflik Papua." Jakarta.

Gau, Sukardi. 2010. "Suku Bugis Dan Bahasanya: Dari Tanah Bugis Ke Tanah Papua ., Hlm. 75-103." In Bahasa Di Selat Makassar Dan Samudera Pasifik, edited by James T. Collins dan Chong Shin (Pnyt.). Bangi: Institut Alam dan Tamadun Melayu, Universiti Kebangsaan Malaysia. 
Hamid, Abu. 2005. Pasompe; Pengembaraan Orang Bugis. II. Makassar: Pustaka Refleksi.

Kesuma, Ima. 2004. Migrasi Dan Orang Bugis: Penelusuran Kehadiran Opu Daeng Rilakka Pada Abad XVIII Di Johor. Yogyakarta: Ombak.

Lacroiz, Duchene, and Koukoutsaki Monnier. 2015. "Mapping the Social Space of Transnational Migrants on the Basis of Their (Supra)National Belongings: The Case of French Citizens in Berlin."

Lineton, Jacqueline A. 1975. "An Indonesian Society and Its University: A Study of the Bugis of South Sulawesi and Their Role Within a Wider Social and Economic System." University of London.

Mattulada. 1983. "Islamisasi Sulawesi Selatan.” In Agama Dan Perubahan Sosial, edited by Taufik Abdullah. Jakarta: CV. Rajawali bekerja sama dengan Yayasan Ilmu-Ilmu Sosial (YIIS). - 1985. Latoa: Satu Lukisan Analitis Terhadap Antropologi Politik Orang Bugis. Yogyakarta: Gadjahmada University Press.

-. 1998. Sejarah, Masyarakat, Dan Kebudayaan Sulawesi Selatan. Ujung Pandang: Hasanuddin University Press.

Muslim, Abu. 2019. "Orang Bugis Di Sulawesi Utara (Islam, Space, Dan Dagang)." In Migran Bugis Dan Pendidikan Islam, edited by Hamdar Arraiyah, 97-139. Bantul: Lintas Nalar.
Pelras, Christian. 2006. The Bugis. Diterjemahkan Oleh Abdul Rahman, Dengan Judul: Manusia Bugis. Jakarta: Nalar.

Pusat Pembinaan dan Pengembangan Bahasa Kementerian Pendidikan Nasional. 2009. Kamus Besar Bahasa Indonesia. Edisi IV. Jakarta: Balai Pustaka.

Rahim, A. Rahman. 1985. Nilai-Nilai Utama Kebudayaan Bugis. Cet. I. Makassar: Lembaga Penerbitan UNHAS.

Rukminto Adi, Isbandi. 2008. Intervensi Komunitas

Pengembangan Masyarakat Sebagai Upaya Pemberdayaan Masyarakat. Jakarta: Rajawali Pers.

Saifuddin, Achmad Fedyani. 2011. Catatan Reflektif Antropologi Sosial Budaya. Jakarta: Institut Antropolgi Indonesia.

Suryawan, I Ngurah. 2014. "Stop Kam Baku Tipu: Pemekaran Daerah, Isu Strategis Pengelolaan Konflik, Dan Transformasi Sosial Di Papua Barat." Jurnal Masyarakat Indonesia 40 (2).

Wekke, Ismail Suardi. 2017. "Migrasi Bugis Dan Madura Di Selatan Papua Barat: Perjumpaan Etnis Dan Agama Di Minoritas Muslim." Jurnal Intelektualita 6 (2). 